\title{
The catastrophic floods of AD 1617 in Catalonia (northeast Spain) and their climatic context
}

\author{
VARYL ROBERT THORNDYCRAFT ${ }^{1 *}$, MARIANO BARRIENDOS ${ }^{2}$, \\ GERARDO BENITO $^{1}$, MAYTE RICO ${ }^{3}$ \& ANGELES CASAS ${ }^{1}$ \\ 1 Institute of Natural Resources, Consejo Superior de Investigaciones Cientificas, Serrano 115-bis, E-28006 Madrid, \\ Spain \\ varyl@ccma.csic.es \\ 2 Department of Modern History, University of Barcelona, B. Reixac s/n, E-08028 Barcelona, Spain \\ 3 Pyrenean Institute of Ecology, Consejo Superior de Investigaciones Cientificas, Avenida Montañana 1005, \\ E-50080 Zaragoza, Spain
}

\begin{abstract}
This paper presents a reconstruction of the catastrophic floods of AD 1617 in Catalonia (northeast Spain). Compilation of archival data sources shows that heavy rainfall occurred from 2 to 6 November 1617 and that the resultant flooding caused severe damage throughout the region, including the destruction of at least 389 houses, 22 bridges and 17 water mills. Discharges of $2700-4500 \mathrm{~m}^{3} \mathrm{~s}^{-9}$ and $\leq 2000 \mathrm{~m}^{3} \mathrm{~s}^{-1}$ were estimated from dated palaeostage indicators for the Ter and Segre rivers, respectively, whilst $4680 \mathrm{~m}^{3} \mathrm{~s}^{-1}$ was calculated for the Llobregat River flood in a previous study (Thorndycraft et al., 2005). The magnitude of the 1617 floods of the Llobregat and Ter rivers exceeded the largest events of the instrumental data series (2300 and $2350 \mathrm{~m}^{3} \mathrm{~s}^{-1}$, respectively). The 1617 floods are also compared to the longer-term palaeoflood record, which shows that the largest floods in the region were associated with colder phases of climatic variability.
\end{abstract}

Key words documentary records; floods; Little Ice Age; northeast Spain; palaeodischarge; palaeoflood hydrology

\section{La crue catastrophique de 1617 en Catalogne (nord-est de l'Espagne) et son contexte climatique}

Résumé Cet article présente une analyse de la crue catastrophique de 1617 en Catalogne (nord-est de l'Espagne). Les sources documentaires montrent que de fortes intensités de pluie ont eu lieu du 2 au 6 novembre 1617 et ont provoqué de graves dommages dans toute la région, avec la destruction d'au moins 389 maisons, 22 ponts et 17 moulins. La modélisation hydraulique a permis de calculer les débits associés aux crues extrêmes de trois bassins (Ter, Segre et Llobregat) à partir des traces laissées par les sédiments de crue, avec respectivement $2700-4500 \mathrm{~m}^{3} \mathrm{~s}^{-1}$ et une valeur inférieure à $2000 \mathrm{~m}^{3} \mathrm{~s}^{-1}$ pour les deux premiers bassins, et $4680 \mathrm{~m}^{3} \mathrm{~s}^{-1}$ pour le troisième d'après l'estimation faite par Thorndycraft et al. (2005). L'intensité de la crue de 1617 sur le Llobregat et le Ter a largement dépassé la plus forte crue enregistrée par le réseau hydrométrique actuel (respectivement 2300 et $2500 \mathrm{~m}^{3} \mathrm{~s}^{-1}$ ). L'événement de 1617 a été resitué dans la chronique pluri-séculaire des paléo-crues, qui montre que les crues les plus fortes ont été associées à des périodes climatiques froides.

Mots clefs sources documentaires; crues; Petit Age Glaciaire; nord-est de l'Espagne; paléo-débits; paléohydrologie

\section{INTRODUCTION}

It is recognized that the most important impacts of climate change on society involve weather-related disasters, in particular floods and droughts (Houghton et al., 2001). However, the current accuracy of general circulation models (GCMs) enables only the projection of mean climatic parameters (monthly temperature and precipitation) at spatial resolutions greater than the size of most river basins. Uncertainties therefore exist regarding the impact of climate change on extreme floods at the basin scale. The relationship of flooding to global environmental change and its associated modelling

* Current address: Department of Geography, Royal Holloway University of London, Egham, Surrey TW20 0EX, UK. 
paradigm is becoming one of the most important Earth science challenges for the new millennium (Baker, 2003). In an analysis of extreme rainfall (90th percentile) using a regional climate model covering the Spanish Mediterranean, it was shown that the predicted increase in rainfall torrentiality exhibited greater spatial variability than at present, irrespective of seasonality (Sánchez et al., 2004). This suggests an even greater level of uncertainty regarding extreme rainfall than exists in the present climate. As well as advances in modelling capabilities, a greater understanding of the climatic and hydrological mechanisms that occurred during past catastrophic floods is needed in order to fully quantify future flood risk. The study of individual catastrophic past floods with regional impacts set in the context of long-term climatic variability can provide a valuable understanding of past, present and future relationships between climate and extreme floods.

Lately, there has been growing research into understanding the climatic variability of recent centuries using historical documentary sources (e.g. Pfister et al., 1999; Brázdil et al., 2005). With respect to floods, documentary archives have mainly been used to: (a) compile flood chronologies (e.g. British Hydrological Society, 1998; Brázdil et al., 1999; Mudelsee et al., 2003; Black \& Law, 2004); (b) estimate flood discharges from known high water marks (e.g. Benito et al., 2003; Naulet et al., 2005); and (c) understand the meteorological causes of the events (e.g. Llasat et al., 2005). The best sedimentary (geomorphologic) archives of past floods are slackwater flood deposits located in bedrock canyons (Baker, 1987). Such palaeoflood investigations can document the magnitude and frequencies of large floods over decades to millennia (e.g. Ely et al., 1993). In Catalonia (northeast Spain), previously published research has focused on reconstructing the palaeoflood record of the Llobregat River (Thorndycraft et al., 2005) and obtaining flood chronologies from documentary archives for the Llobregat, Segre and Ter basins (Llasat et al., 2005). The combination of palaeoflood and documentary records (Table 1) has the potential to reduce the uncertainties associated with both methodologies and provide a more holistic approach that can strengthen our understanding of past floods, as illustrated for the Ardeche River in France (Sheffer et al., 2003). In this paper we analyse the extreme event of November 1617 in Catalonia, which, in a previous study, was highlighted as one of the largest floods of the Llobregat River over the last 3000 years (Thorndycraft et al., 2005). The main objectives of this paper are to: (1) estimate the 1617 flood discharge for the main rivers in the region, namely the Segre, Llobregat and Ter rivers; (2) reconstruct the main socio-economic impacts of the 1617 event throughout Catalonia; (3) determine the weather pattern and meteorological behaviour of the 1617 event; and (4) compare flood magnitudes of this event with other palaeoflood and instrumental flood records from the study basins.

\section{STUDY BASINS}

The principal study basins discussed in this paper are those of the Ter, Llobregat and Segre rivers (Fig. 1), which have drainage areas of 3295, 5455 and $11068 \mathrm{~km}^{2}$, respectively. The largest floods registered in the instrumental record (from gauge stations adjacent to the study reaches) are listed in Table 2. These occurred in 1940 in the Ter River $\left(2350 \mathrm{~m}^{3} \mathrm{~s}^{-1}\right), 1971$ in the Llobregat River $\left(2300 \mathrm{~m}^{3} \mathrm{~s}^{-1}\right)$ and 1982 in the 
Table 1 Comparison between palaeoflood and historical research methodologies for reconstructing past flood events.

\begin{tabular}{|c|c|c|}
\hline $\begin{array}{l}\text { Type of } \\
\text { information }\end{array}$ & Palaeoflood hydrology & Documentary sources \\
\hline \multirow[t]{2}{*}{$\begin{array}{l}\text { Floodwater } \\
\text { elevation }\end{array}$} & \multirow{2}{*}{$\begin{array}{l}\text { Slackwater flood deposits indicate the } \\
\text { minimum elevation reached by } \\
\text { floodwaters. Water depth above } \\
\text { sediments is unknown, though can be } \\
\text { estimated through sedimentological } \\
\text { analysis. }\end{array}$} & $\begin{array}{l}\text { Where they exist, historical flood marks } \\
\text { provide an indication of flood water } \\
\text { elevation. }\end{array}$ \\
\hline & & $\begin{array}{l}\text { Relative flood magnitude often difficult } \\
\text { to assess if no flood marks available - } \\
\text { dependent on impacts not necessarily } \\
\text { magnitude. }\end{array}$ \\
\hline \multirow[t]{3}{*}{$\begin{array}{l}\text { Discharge } \\
\text { estimation }\end{array}$} & \multirow{3}{*}{$\begin{array}{l}\text { Slackwater flood deposits found in } \\
\text { bedrock canyons with limited channel } \\
\text { change over centennial timescales. This } \\
\text { results in stable valley cross-sections } \\
\text { with little channel incision over centuries } \\
\text { to millennia, enabling accurate discharge } \\
\text { estimation through hydraulic modelling. }\end{array}$} & $\begin{array}{l}\text { Very complex due to urban growth } \\
\text { and/or location of towns on alluvial } \\
\text { floodplains with greater potential for } \\
\text { historical channel change. }\end{array}$ \\
\hline & & Known floodwater elevations required. \\
\hline & & $\begin{array}{l}\text { Detailed historical maps and } \\
\text { information on past infrastructures e.g. } \\
\text { bridges, dykes etc. essential. }\end{array}$ \\
\hline \multirow[t]{3}{*}{ Flood chronology } & \multirow{3}{*}{$\begin{array}{l}\text { Errors associated with }{ }^{14} \mathrm{C} \text { and Optically } \\
\text { Stimulated Luminescence dating. Can } \\
\text { identify periods of increased flood } \\
\text { frequency at centennial/millennial } \\
\text { temporal resolution. } \\
\text { Possible gaps in record due to erosion. }\end{array}$} & $\begin{array}{l}\text { Can provide information at hourly or } \\
\text { daily resolution. }\end{array}$ \\
\hline & & $\begin{array}{l}\text { Gaps in record due to loss or destruction } \\
\text { of archival sources, e.g. during wars. }\end{array}$ \\
\hline & & \\
\hline $\begin{array}{l}\text { Meteorological } \\
\text { conditions }\end{array}$ & - & $\begin{array}{l}\text { Can identify a number of } \\
\text { meteorological characteristics, e.g. days } \\
\text { with rainfall, relative rainfall intensity, } \\
\text { wind direction and temperature changes. }\end{array}$ \\
\hline Flood impacts & $\begin{array}{l}\text { Reconstructed flood discharges can be } \\
\text { routed through particular river reaches of } \\
\text { a basin, using hydraulic modelling, to } \\
\text { estimate potential impact. }\end{array}$ & $\begin{array}{l}\text { Information on casualties; destruction of } \\
\text { buildings and infrastructures; economic } \\
\text { losses etc. }\end{array}$ \\
\hline
\end{tabular}

Segre $\left(2300 \mathrm{~m}^{3} \mathrm{~s}^{-1}\right)$. Each basin has a long historical flood chronology with records beginning in 1322, 1315 and 1306 for the Ter, Llobregat and Segre basins, respectively. The palaeoflood records span approximately 17000 years in the Segre River (Rico, 2004); 3000 years in the Llobregat River (Thorndycraft et al., 2005) and 350 years in the Ter basin (this paper).

\section{METHODOLOGY}

\section{Compiling past flood information from sedimentary records - palaeoflood hydrology}

Palaeoflood hydrology is the reconstruction of the magnitude and frequency of recent, past, or ancient floods using geomorphological evidence. Most commonly used are slackwater flood deposits, which indicate the minimum water surface elevation of past floods and can be used to estimate flood magnitude and frequency (Baker, 1987; Benito et al., 2003). During high-flood stages in river gorges, eddies, back-flooding and water stagnation occur at the valley sides, producing low velocities and/or flow stagnation that favours deposition of clay, silt and sand. At the study reaches (Fig. 1), sites of slackwater sediment deposition were identified. Sections were cut to expose 


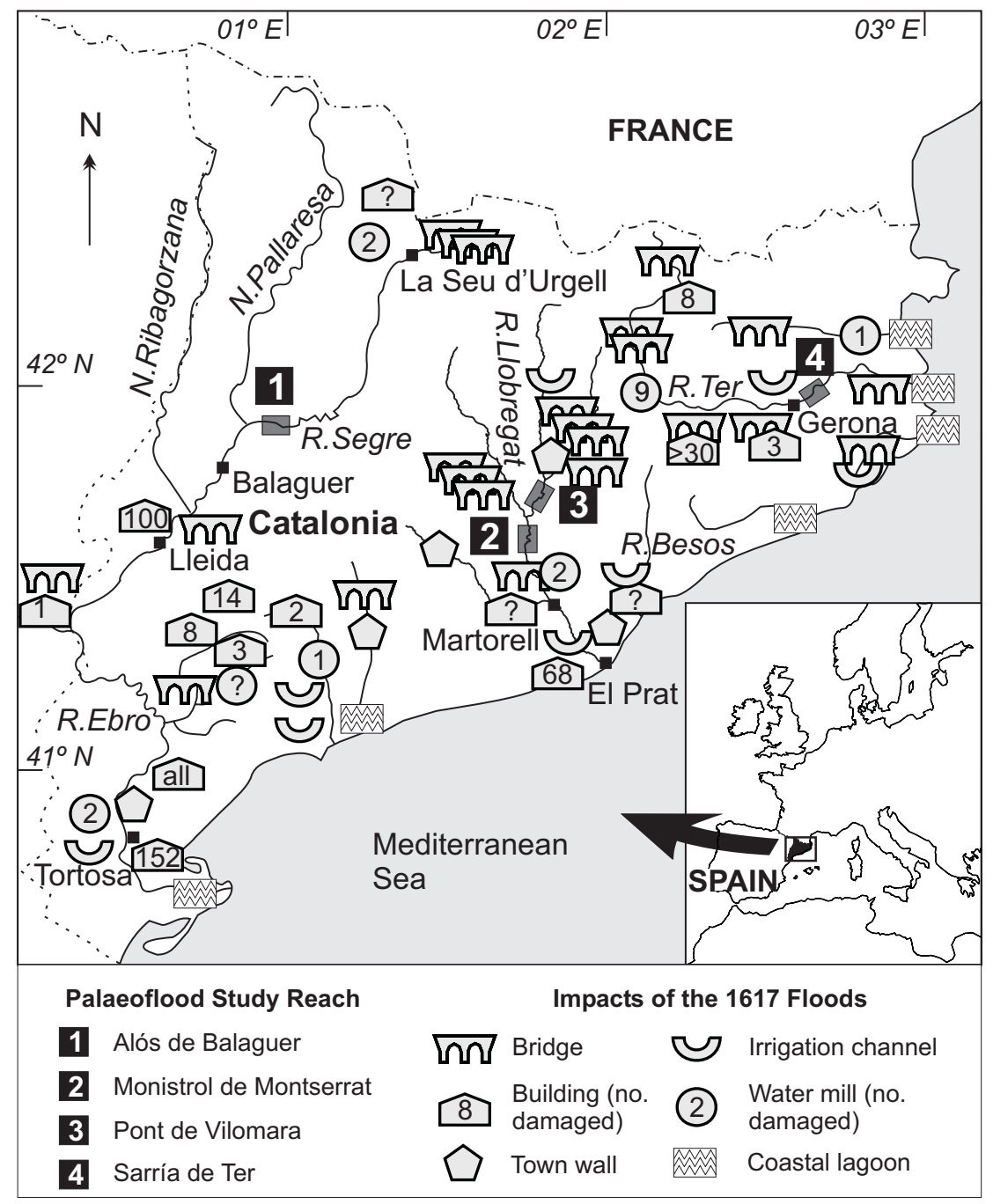

Fig. 1 Map showing the location of the palaeoflood study reaches and the major societal impacts of the 1617 floods in Catalonia.

Table 2 Summary of the different flood records at the study reaches.

\begin{tabular}{|c|c|c|c|c|c|c|}
\hline $\begin{array}{l}\text { Basin and } \\
\text { study reach } \\
\text { location }\end{array}$ & $\begin{array}{l}\text { Drainage } \\
\text { area } \\
\left(\mathrm{km}^{2}\right)\end{array}$ & $\begin{array}{l}\text { Period of } \\
\text { gauge } \\
\text { station } \\
\text { operation }\end{array}$ & $\begin{array}{l}\text { Largest } \\
\text { recorded } \\
\text { discharge } \\
\left(\mathrm{m}^{3} \mathrm{~s}^{-1}\right) \text { and } \\
\text { date }\end{array}$ & $\begin{array}{l}\text { Interval of } \\
\text { historical } \\
\text { record in the } \\
\text { whole basin }\end{array}$ & $\begin{array}{l}\text { Length of } \\
\text { palaeoflood } \\
\text { record (years) }\end{array}$ & $\begin{array}{l}\text { Calculated } \\
\text { palaeo- } \\
\text { discharge } \\
\left(\mathrm{m}^{3} \mathrm{~s}^{-1}\right)\end{array}$ \\
\hline \multicolumn{7}{|l|}{ Ter } \\
\hline Gerona & 1802 & $1912-1998$ & $\begin{array}{l}2350 \\
(18 / 10 / 1940)\end{array}$ & $\begin{array}{l}1322-1987 \\
\text { (172 floods) }\end{array}$ & c. 400 & $2700-4500$ \\
\hline \multicolumn{7}{|l|}{ Llobregat } \\
\hline $\begin{array}{l}\text { Pont de } \\
\text { Vilomara }\end{array}$ & 1845 & $\begin{array}{l}1915-1922 \\
1943-\end{array}$ & $\begin{array}{l}1650 \\
(20 / 09 / 1971)\end{array}$ & $\begin{array}{l}1315-1992 \\
\text { (158 floods) }\end{array}$ & $\begin{array}{l}\text { c. } 3000 \\
\text { (no dated LIA } \\
\text { flood) }\end{array}$ & $3700-4300$ \\
\hline Monistrol & 3370 & $1942-$ & $\begin{array}{l}2300 \\
(20 / 09 / 1971)\end{array}$ & & c. 400 & 4860 \\
\hline \multicolumn{7}{|l|}{ Segre } \\
\hline $\begin{array}{l}\text { Alós de } \\
\text { Balaguer }\end{array}$ & 4318 & 1944-1983 & $\begin{array}{l}2300 \\
(08 / 11 / 1982)\end{array}$ & $\begin{array}{l}1306-1982 \\
\text { (51 floods) }\end{array}$ & c. 17000 & 1900 \\
\hline
\end{tabular}


Table 3 Information concerning the radiocarbon dates discussed in the text. All samples were dated by the Accelerator Mass Spectrometry method at the Institute of Particle Physics of the Swiss Federal Institute of Technology, Zurich. Flood unit numbers refer to the stratigraphic columns in Fig. 3, except units A4 and A5 which refer to Fig. 5 of Thorndycraft et al. (2005).

\begin{tabular}{llllll}
\hline Study reach & $\begin{array}{l}\text { Flood } \\
\text { unit no. }\end{array}$ & Sample material & Laboratory code & $\begin{array}{l}\text { Age } \\
\text { (years BP) }\end{array}$ & $\begin{array}{l}\text { Two sigma } \\
\text { calibrated age } \\
\text { range (95.4\%) }\end{array}$ \\
\hline $\begin{array}{l}\text { Llobregat: } \\
\text { Monistrol }\end{array}$ & L1 & Charcoal & UZ-4605/ETH-24418 & $305 \pm 50$ & AD 1460-1670 \\
$\begin{array}{l}\text { Llobregat: } \\
\begin{array}{l}\text { Pont de } \\
\text { Vilomara }\end{array}\end{array}$ & A5 & Charcoal & UZ-4523/ETH-23673 & $2640 \pm 55$ & $\begin{array}{l}930-750 \text { BC } \\
(88.5 \%)\end{array}$ \\
& & Charcoal & UZ-4524/ETH-23674 & $2580 \pm 75$ & $\begin{array}{l}840-480 \text { BC } \\
(88.8 \%)\end{array}$ \\
$\begin{array}{l}\text { Segre: } \\
\text { Alós de } \\
\text { Balaguer }\end{array}$ & S2 & Charcoal & UZ-4740/ETH-25511 & $1120 \pm 50$ & AD 780-1020 \\
\hline
\end{tabular}

the sedimentary sequences. Individual flood units were determined through a close inspection of depositional breaks and/or indicators of surficial exposure, such as bioturbation. Flood chronology was determined by radiocarbon dating carried out on charcoal samples collected from individual flood units (Table 3). In addition, at the Ter site, a coin was found buried by slackwater deposits. The coin was dated to AD 165152 (see Appendix 1 for details).

\section{Compiling past flood information from archival sources}

In Catalonia, the recording of destructive events, such as floods or droughts, was undertaken by public institutions in order to provide information for future decision making as communities were especially dependent upon rivers for drinking water, water power and irrigation. These administrative sources (e.g. town council resolution books and public works files) were the main types consulted in this study due to their optimal objectivity. Other sources used included chronicles, diaries or books written by individuals or corporations. The objectivity or continuity of the information are not guaranteed; however, these types of documents can usually provide useful anecdotal details. In total, 903 manuscript volumes from different documentary series were consulted in the three study basins, with 1227 additional manuscript volumes used from elsewhere in Catalonia. Of these, 27 documents (and nine further bibliographic sources) were specifically concerned with the 1617 event (see Appendix 2 for a list of the data sources).

The available information concerning floods, relevant to this study, can be divided into three types. Firstly, the general meteorological conditions may be described, for example, the occurrence of torrential or persistent rain, the date and time a storm began and its duration and the prevailing wind direction. Often the information is sufficient to understand the cause of the flood. Secondly, there may be precise descriptions about the nature of the flooding, for example the dates of overbank flows, characteristics of the floodwaters such as the strength of flow or the maximum elevation reached by the floodwaters. In some cases the latter is preserved by marks and dates etched onto the sides of buildings. Finally, an assessment of flood impacts can be estimated as the authorities made descriptions of the damage caused. 


\section{Palaeodischarge estimation}

The estimation of palaeodischarge from slackwater flood deposits or historical flood marks (palaeostage indicators) was carried out by computing the water surface profiles for various hypothetical discharges that were routed through the surveyed study reaches. The hydraulic modelling was carried out through the step-backwater method (Webb \& Jarrett, 2002) using the HEC-RAS one-dimensional model (Hydrologic Engineering Center, 1995) run within a GIS environment. Palaeodischarge estimates were obtained by matching the model-generated water surface profiles to the elevation of the palaeostage indicators, except for the Monistrol palaeoflood deposits. In this specific case, channel flow velocity was over $6 \mathrm{~m} \mathrm{~s}^{-1}$ with subcritical flow conditions (Froude Number about 0.5), indicating a sharp velocity transition from the main channel to the canyon side where the slackwater flood sediments illustrated deposition in stagnant water conditions (Thorndycraft et al., 2005). Assuming that the sedimentation at the alcove (where the velocity head equals zero) was close to the maximum flow stage and, therefore, related to the total energy head for the cross-section, the palaeodischarge was obtained by matching the energy line (rather than the water surface profile) to the palaeostage evidence. Further information on the hydraulic modelling, including details of the roughness coefficients used and the surveys, are presented in Thorndycraft et al. (2005) and Casas et al. (2006).

\section{THE 1617 EVENT}

\section{Historical reconstruction of the event}

The storm began on 2 November with a front of torrential rain passing over coastal areas of Catalonia (Fig. 2(a)). The area initially affected was not extensive; however, a shift in wind direction on 3 November (to predominantly southeasterlies or southerlies) caused the rainfall to move further inland and cover the whole of Catalonia. The first floods recorded in the documentary record occurred on the morning of 3 November in small coastal basins such as the Besos River (Fig. 1; Fig. 2(a)). By the evening, there was flooding in Seu d'Urgell in the upper Segre catchment. The orographic effect of the Pyrenees led to high rainfall that lasted for many hours (3-4 November) in the headwaters of the main Catalan rivers. After a brief period of respite, coastal areas were hit by further torrential rain (5-6 November), this time resulting from dispersed convective activity. As a result of this prolonged heavy rainfall there was severe flooding documented in river basins throughout Catalonia.

The known damage in the region was the destruction of 389 houses, 17 water mills and 22 bridges; partial damage to six city walls and the rupture of seven irrigation canals (Fig. 1). The most severely affected reaches occurred at Lleida in the Segre basin (where the Cappont neighbourhood was totally destroyed), Tortosa at the mouth of the River Ebro and the lower reaches of both the Llobregat and Ter rivers. In addition to the direct impacts of damage to infrastructures, communication routes and crops, there were other impacts more difficult to quantify. The destruction of mills resulted in the loss of a basic source of energy, impeding flour production and resulting in famine in the largest towns. Furthermore, the floodwaters formed a number 
(a)

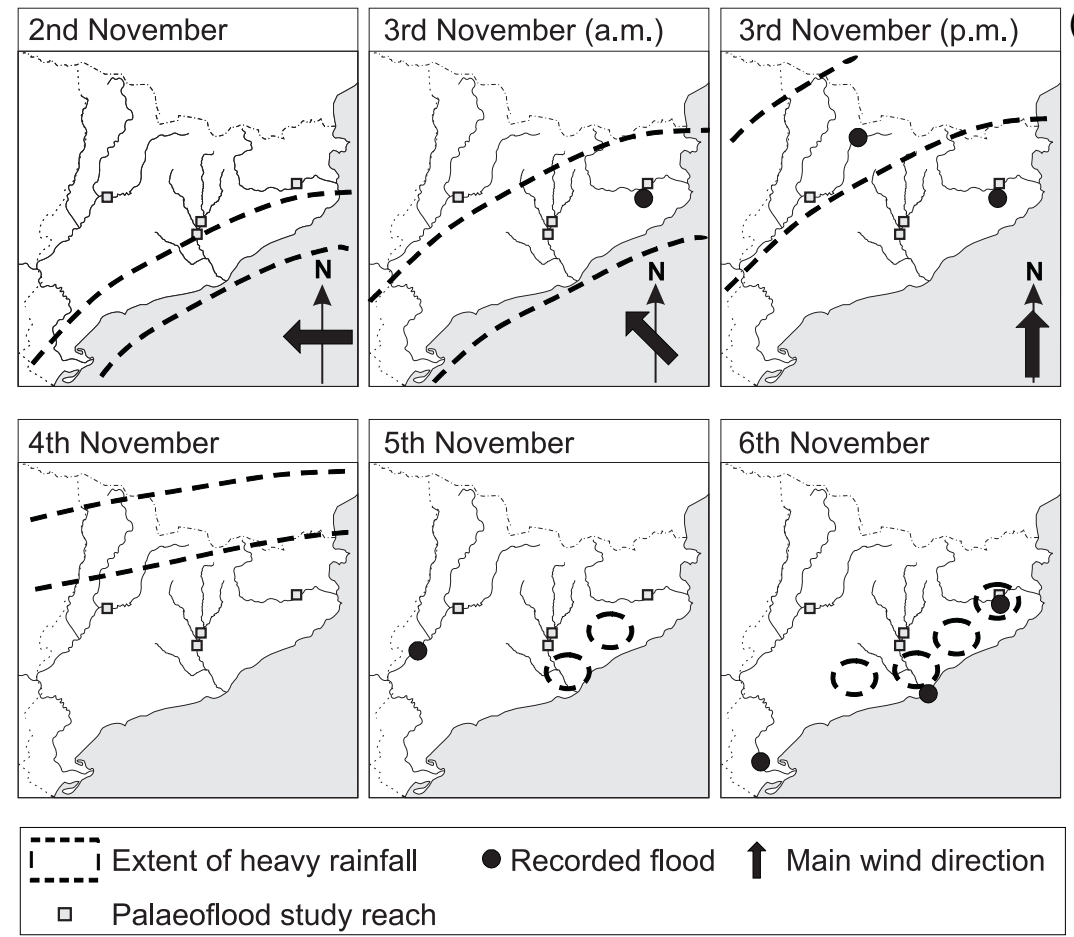

(b)
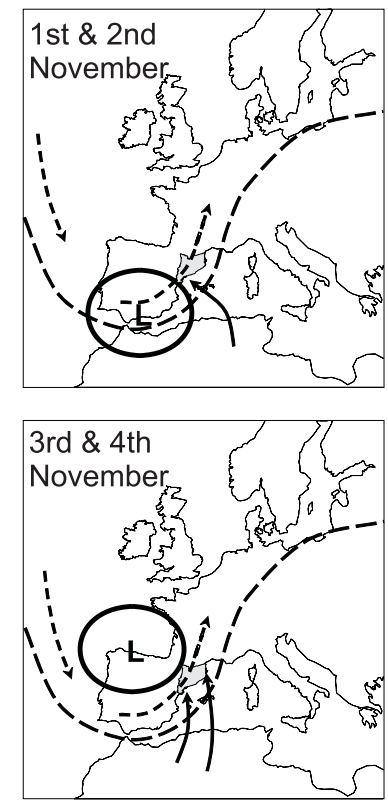

-.-. High level situation

$\sim$ Surface situation

Fig. 2 (a) Reconstruction of the 1617 extreme rainfall event compiled from documentary sources; and (b) proposed synoptic conditions that caused the rainfall.

of coastal lagoons (Fig. 1) that took more than a year to dry, resulting in increased levels of mosquitoes and associated diseases within the coastal population.

\section{Estimating discharge of the 1617 floods}

The sedimentary evidence for the 1617 flood in the Llobregat, Ter and Segre river basins is presented in Fig. 3. At the Monistrol de Montserrat reach of the Llobregat River a single slackwater flood unit was discovered in a valley side alcove located approximately $16 \mathrm{~m}$ above the river bed (Fig. 3(c)). The deposit was dated to cal. AD 1460-1670 (Table 3). This date and the exceptional altitude of the deposits, when cross-referenced with the documentary flood record from the basin, imply that the sediments were most likely deposited by the 1617 flood (Thorndycraft et al., 2005), the most extreme to have occurred during the last seven centuries according to flood marks at Martorell and El Prat del Llobregat (located at the delta reach). These flood marks indicate the severe magnitude of the flood. However, an accurate discharge is difficult to quantify due to urbanization, the construction of major road and rail infrastructure and, in the case of El Prat, complex hydraulics due to its location on the delta. The palaeoflood study reach at Monistrol, located in a stable bedrock gorge with limited human impact, enabled a more accurate discharge to be calculated. Hydraulic modelling (Thorndycraft et al., 2005) resulted in a minimum discharge of $4680 \mathrm{~m}^{3} \mathrm{~s}^{-1}$ for the flood (Fig. 3(c)).

The evidence from the Ter basin comes from the lower catchment, in a study reach downstream of Gerona (Fig. 1). A flood mark located $3.6 \mathrm{~m}$ above street level on the 

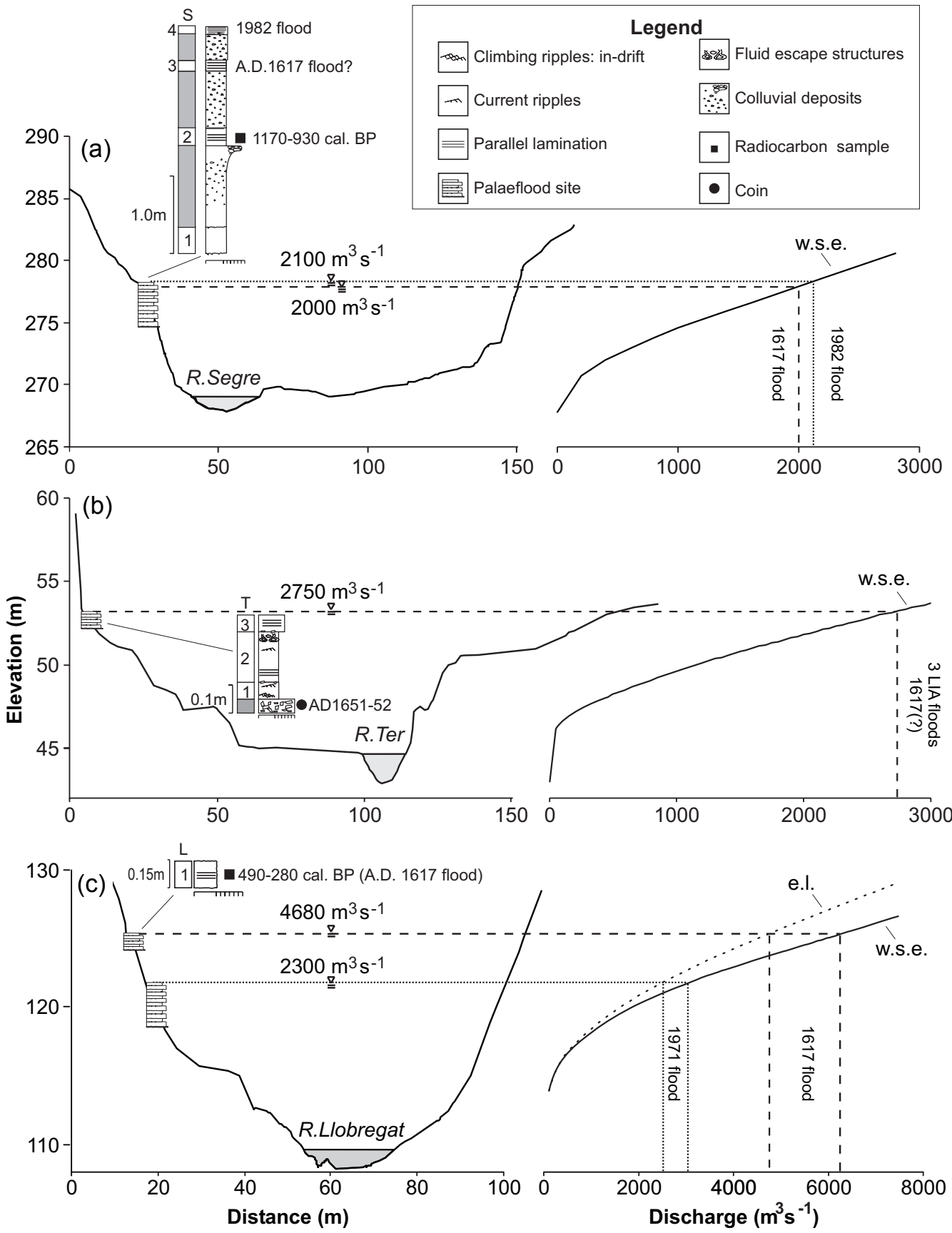

Fig. 3 Cross-sections of key localities at the palaeoflood study reaches illustrating the location of slackwater flood deposits, their chronology and the discharge rating curve (where w.s.e. = water surface elevation; e.l. = energy line): (a) Alós de Balaguer; (b) Sarría de Ter; and (c) Monistrol de Montserrat. Flood units discussed in the text are identified by initial and number (e.g. S2 refers to the flood deposit of the Segre River dated to $1170-920 \mathrm{cal}$. BP).

Pont Mayor parish church (Fig. 4) illustrates the extreme elevation of the floodwaters. Hydraulic modelling at this reach of the river indicates a discharge of $4500 \mathrm{~m}^{3} \mathrm{~s}^{-1}$, a similar magnitude to that of the Llobregat River discussed above. The estimate may contain errors because the cross-section is unstable, as it is an alluvial reach of the 


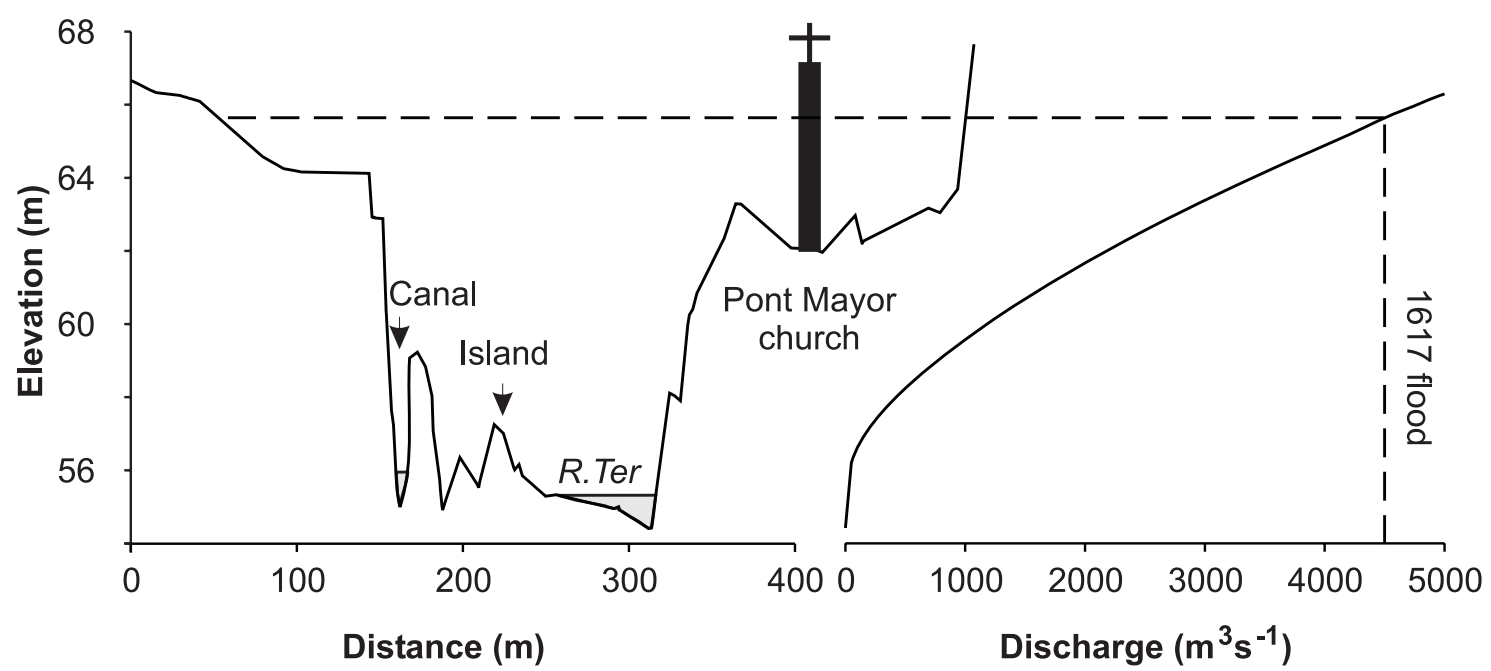

Fig. 4 Cross-section of the Ter River showing the elevation of the 1617 flood according to a flood mark on the wall of the Pont Mayor church (Sarría de Ter reach). Also shown is the associated discharge rating curve.

river and in an urbanized area. However, the value of $4500 \mathrm{~m}^{3} \mathrm{~s}^{-1}$ combined with the physical evidence of the flood mark indicate that the 1617 flood was substantially greater than the $2350 \mathrm{~m}^{3} \mathrm{~s}^{-1}$ recorded during the 1940 flood, the largest in the instrumental record (Table 2). Downstream of Sarría de Ter a site of slackwater flood deposition was found where the Ter narrows as it passes through the littoral mountain range. There is no sedimentary evidence for the 1617 flood here as the three flood units (Fig. 3(b)) post-date a buried coin stamped in AD 1651 or 1652 (see Appendix 2). Hydraulic modelling indicates a minimum discharge of $2750 \mathrm{~m}^{3} \mathrm{~s}^{-1}$ for a flood to inundate the alcove. This is substantially lower than the flood mark discharge of $4500 \mathrm{~m}^{3} \mathrm{~s}^{-1}$. It appears that the alcove was repeatedly inundated during the Little Ice Age (LIA), for example at least three floods are known to have occurred between the late 17th and 19th centuries from the palaeoflood evidence (Fig. 3(b). It is probable, therefore, that the flood sediments here were exposed to erosion. Despite there being no direct physical evidence for the 1617 event, this palaeoflood site provides a conservative lower bound threshold of $2750 \mathrm{~m}^{3} \mathrm{~s}^{-1}$ for the flood.

The sedimentary record from the Alós de Balaguer study reach of the Segre River (Fig. 3(a)) consistently shows evidence for three to four large floods (depending on the site of deposition) over the last millennium (Rico, 2004). In the section illustrated in Fig. 3(a), three flood units, separated by gravely colluvium, are preserved. The earliest flood was radiocarbon dated to 930-1170 cal. BP, whilst the upper flood sediments were deposited by the 1982 flood, the sediments of which were mapped along the study reach and dated by the presence of anthropogenic materials such as sweet wrappers (Rico, 2004). Prior to the modern period, three catastrophic floods (observed at Seu d'Urgell, Balaguer and Lleida (Fig. 1) in the upper, middle and lower reaches, respectively) have been recorded since AD 1317 (namely 1617, 1726 and 1853). Historical evidence indicates that the 1617 flood was one of the largest and most catastrophic on record, destroying bridges, water mills and houses at Seu d'Urgell and the entire Cappont neighbourhood at Lleida. Whether the undated deposits (S3, in Fig. 3) were a result of the 1617 flood or not, there is no evidence at this reach to 
suggest that the 1617 flood was of greater magnitude than that of 1982 . Hydraulic modelling resulted in a minimum discharge of $2000 \mathrm{~m}^{3} \mathrm{~s}^{-1}$ for the $\mathrm{S} 3$ deposits, which compares with $2300 \mathrm{~m}^{3} \mathrm{~s}^{-1}$ for the 1982 event.

\section{DISCUSSION}

Various syntheses of LIA climate (e.g. Bradley \& Jones, 1992) indicate a scenario of climatic irregularity, with phases of high frequency of extraordinary events (floods or droughts) contrasting with phases characterized by similar conditions to those of the Medieval Warm Period (c. 8-13th centuries, Hughes \& Diaz, 1994) or the present day. One of the climatic anomalies that occurred during the LIA in Catalonia was an increase in the frequency of catastrophic flooding (Barriendos \& Martín-Vide, 1998; Llasat et al., 2005), in particular during decades centred around AD 1600, 1790 and 1850. The 1617 flood occurred during the earliest of these documented periods. Despite the scarcity of available meteorological data almost four centuries ago, the reconstruction of the 1617 event from information on wind directions and rainfall timing (Fig. 2) allows comparison to be made with more recent events for which instrumental records are available. The atmospheric situation that could have led to the severe 1617 rainfall is similar to that of a low pressure cell that slowly tracks the Spanish coast after either entering the Mediterranean from the Atlantic in the Gulf of Cádiz area, or originating in the western Mediterranean basin (Fig. 2(b)). There was probably an associated blocking anticyclone to the east of Catalonia, coinciding with high-level cold air over Western Europe. The result was a cold centred depression that would explain the severity and duration of the intense rainfall. In general, the extreme floods during this period were probably the result of the prevailing meridional circulation patterns caused by anticyclonic blocking over Eastern Europe (Luterbacher et al., 2002; Jacobeit et al., 2003), with northerly cold air masses coinciding with warm, humid air masses over the Mediterranean Sea. This synoptic situation also led to other catastrophic flood events in the region, for example the Ebro River flood of 2-8 October 1787 (unpublished data), or the event of 16-20 October 1940 (Llasat, 1993). Such blocking situations over Western Europe had the potential to cause long periods of adverse meteorological conditions, such as heavy rainfalls, cold spells or droughts (Barriendos \& Llasat, 2003), the specific hydrological response dependent upon the exact location of the high pressure cells.

The timing and pattern of rainfall across Catalonia is reflected in the discharge estimates obtained for the 1617 floods of the Llobregat, Ter and Segre rivers. The most extreme flood discharges occurred in the Ter and Llobregat basins, where the floods were significantly larger than (around double) the highest magnitude events recorded in the instrumental record. By contrast, the more westerly located Segre, though severely affected in terms of socio-economic damage, witnessed a discharge probably similar to that of the 1982 flood. This reflects the fact that the convective rainfall that occurred on 5-6 November 1617 affected the littoral basins more than the inland Segre basin. The extreme hydrological conditions of the 1617 flood event are represented in the regional envelope curve (Fig. 5) where the palaeoflood and historical flood discharges are plotted alongside the maximum floods recorded at gauging stations across Catalonia and eastern Aragon, which has a similar hydrological regime. The palaeo- 


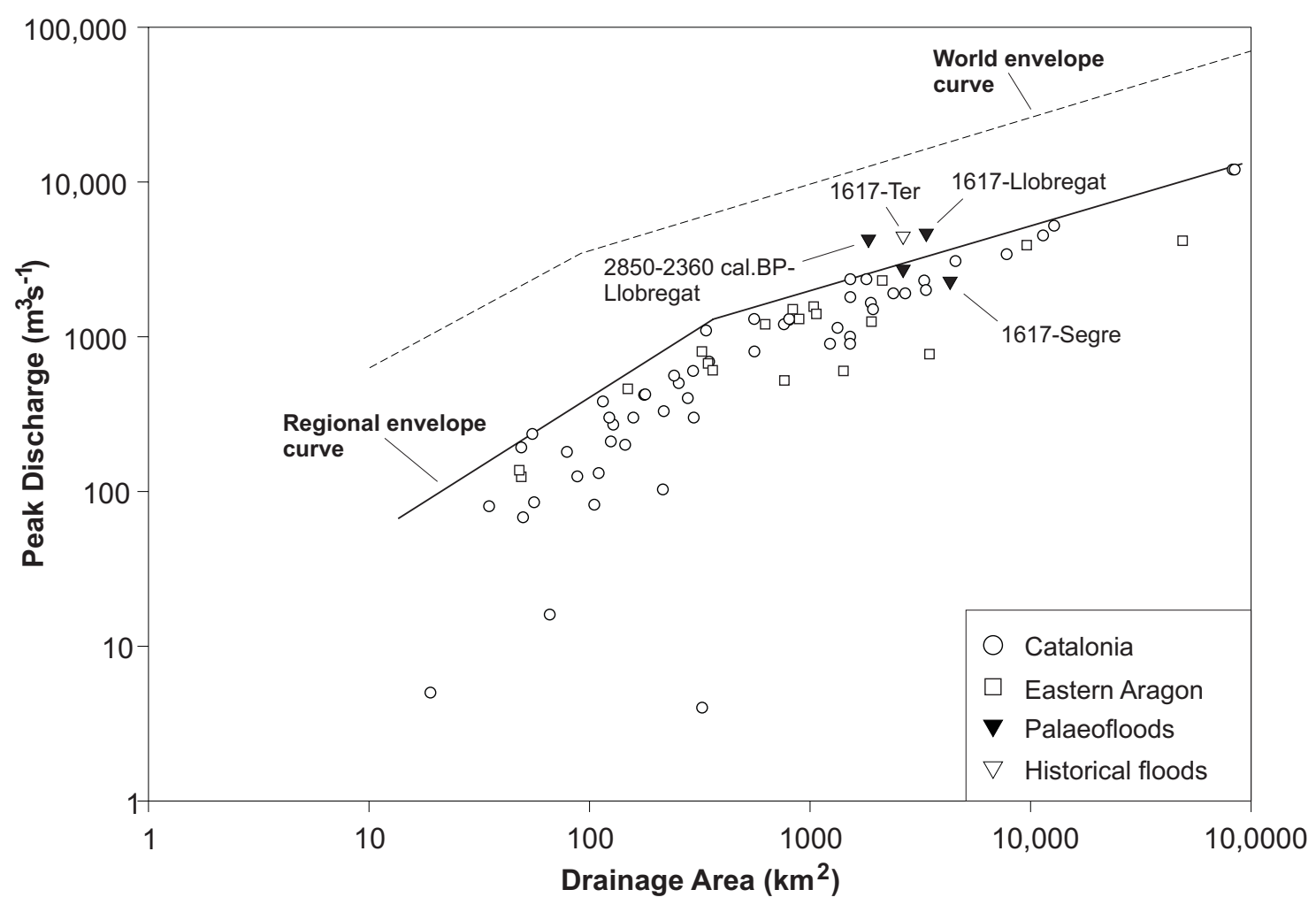

Fig. 5 Regional envelope curve for Catalonia and eastern Aragon. Palaeodischarges from palaeoflood deposits and historical flood information are plotted. Also shown for comparison is the world envelope curve produced from the data in Rodda (2003).

flood discharge data from the Ter and Llobregat rivers plot substantially above the regional envelope curve (by contrast, that of the Segre River plots below).

Also presented on the envelope curve (Fig. 5) are palaeoflood discharges from the Pont de Vilomara study reach (Fig. 1) of the Llobregat River. The discharges here are of similar magnitude to the 1617 flood at Monistrol; however, no absolute dating has yet indicated LIA flood sediments preserved at this site of deposition. However, radiocarbon dating does identify five major floods during the last 3000 years (Thorndycraft et al., 2005), with two events dated to 2880-2500 cal. BP and 2850-2360 cal. BP (Table 3). This evidence can be used to place the 1617 floods in a longer-term context of climatic variability. There is significant evidence from across Europe, and from North Atlantic deep-sea sediment cores (e.g. Bond et al., 2001), showing that the Late Bronze Age period experienced a cold phase of climate, specifically dated to 2850 cal. BP by van Geel et al. (1998), who relate the cooling to solar forcing. The analysis of past flood events in Catalonian basins, therefore, suggests that the most extreme flood magnitudes of the last 3000 years occurred in response to a colder climate in Europe.

\section{CONCLUSIONS}

The value of utilizing a combined palaeoflood and historical methodological approach for obtaining data on floods that occurred prior to the instrumental period has been illustrated through a reconstruction of the 1617 floods in Catalonia. Cross-referencing 
the palaeoflood chronology with flood inventories compiled from archival sources can reduce the inherent uncertainties associated with the techniques (e.g. radiocarbon) used to date flood sediments. Hence the high-elevation L1 flood deposits of the Llobregat River (Fig. 3(c)), radiocarbon dated to 490-280 cal. BP, could be assigned to the 1617 flood, as the documentary evidence pointed to this event being the most extreme in the historical record. In addition, documentary records can provide information concerning the timing of the flood, meteorological aspects of the event and the socio-economic consequences. The principal advantage of palaeoflood hydrology is that it provides accurate discharge estimates for past floods as palaeoflood sediments are located in bedrock river reaches with stable cross-sections avoiding the complexities of hydraulic modelling in urbanized areas. With respect to the 1617 event, intense rainfall occurred over an unusually long period (from 2 to 6 November) and resulted in minimum discharges of $4680 \mathrm{~m}^{3} \mathrm{~s}^{-1}$ and $2750-4500 \mathrm{~m}^{3} \mathrm{~s}^{-1}$ at the study reaches of the Llobregat and Ter rivers, respectively. These discharge values plot significantly above the regional envelope curve (Fig. 5). The extreme rainfall was triggered by anomalous meteorological patterns that were a consequence of decadal-scale climatic variability during the Little Ice Age. The period AD 1580-1620, with colder temperatures and frequent blocking situations over Eastern Europe that led to more frequent storm fronts affecting Catalonia, was one of increased flood frequency in the region (Llasat et al., 2005). Similar meteorological patterns may also have been encountered during the cold phase of the Late Bronze Age (c. 2850 cal. BP), accounting for the extreme floods of the Llobregat basin radiocarbon dated to this time.

Acknowledgements This research was carried out within the SPHERE project (Systematic, Palaeoflood and Historical data for the improvEment of flood Risk Estimation) funded by the EC VI Framework Programme (EVG1-CT-1999-00010). M. Barriendos acknowledges the support of the "Ramon y Cajal" Research Programme (Spanish Ministry of Science and Education). We would also like to thank the F. Calicó Company in Barcelona for dating the coin and two anonymous reviewers whose comments helped improve the manuscript.

\section{REFERENCES}

Baker, V. R. (1987) Paleoflood hydrology and extraordinary flood events. J. Hydrol. 96, 79-99.

Baker, V. R. (2003) A bright future for old flows: origins, status and future of palaeoflood hydrology. In: Palaeofloods, Historical Data \& Climatic Variability: Applications in Flood Risk Assessment (ed. by V. R. Thorndycraft, G. Benito, M. Barriendos \& M. C. Llasat), 13-18. CSIC (Consejo Superior de Investigaciones Científicas), Madrid, Spain.

Barriendos, M. \& Martín-Vide, J. (1998) Secular climatic oscillations as indicated by catastrophic floods in the Spanish Mediterranean coastal area (14th-19th centuries). Climatic Change 38, 473-491.

Barriendos, M. \& Llasat, M. C. (2003) The case of the "Maldá" anomaly in the western Mediterranean basin (AD 17601800): an example of a strong climatic variability. Climatic Change 61, 191-216.

Benito, G., Sánchez-Moya, Y. \& Sopeña, A. (2003) Sedimentology of high-stage flood deposits of the Tagus River, Central Spain. Sediment. Geol. 157, 107-132.

Black, A. R. \& Law, F. M. (2004) Development and utilization of a national web-based chronology of hydrological events. Hydrol. Sci. J. 49(2), 237-246.

Bond, G., Kromer, B., Beer, J., Muscheler, R., Evans, M. N., Showers, W., Hoffmann, S., Lotti-Bond, R., Hajdas, I. \& Bonani, G. (2001) Persistent solar influence on North Atlantic climate during the Holocene. Science 294, 2130-2136.

Bradley, R. S. \& Jones, P. D. (1992) Climate Since A.D.1500. Routledge, London.

Brázdil, R., Glaser, R., Pfister, C., Antoine, J. M., Barriendos, M., Camuffo, D., Deutsch, M., Enzi, S., Guidoboni, E. \& Rodrigo, F. S. (1999) Flood events of selected rivers of Europe in the Sixteenth Century. Climatic Change 43, 239-285. 
Brázdil, R., Pfister, C., Wanner, H., von Storch, H. \& Luterbacher, J. (2005) Historical climatology in Europe - the state of the art. Climatic Change 70, 363-430

Calicó, F., Calicó, X. \& Trigo, J. (1998) Monedas españolas desde Fernando e Isabel a Juan Carlos I. Años: 1474 a 1998. Xavier Calicó Estivill, Barcelona, Spain.

Casas A., Benito G., Thorndycraft V. R. \& Rico M. (2006) The topographic data source of digital terrain models as a key element in the accuracy of hydraulic flood modelling. Earth Surf. Processes Landf. 31, 444-456.

Ely, L. L., Enzel, Y., Baker, V. R. \& Cayan, D. R. (1993) A 5000-year record of extreme floods and climate change in the southwestern United States. Science 262, 410-412.

Houghton, J. T., Ding, Y., Griggs, D. J., Noguer, M., van der Linden, P. J., Dai, X., Maskell, K. \& Johnson, C. A. (2001) Climate Change 2001: The Scientific Basis. Contribution of Working Group I to the Third Assessment Report of the Intergovernmental Panel on Climate Change. Cambridge Univ. Press, Cambridge, UK.

Hughes, M. K. \& Diaz, H. F. (1994) The Medieval Warm Period. Kluwer, Dordrecht, The Netherlands.

Hydrologic Engineering Center (1995) HEC-RAS, River Analysis System, Hydraulics Reference Manual (CPD-69). US Army Corps of Engineers.

Jacobeit, J., Glaser, R., Luterbacher, J., Nonnenmacher, M. \& Wanner, H. (2003) Links between flood events in central Europe since AD 1500 and the large-scale atmospheric circulation. In: Palaeofloods, Historical Data \& Climatic Variability: Applications in Flood Risk Assessment (ed. by V. R. Thorndycraft, G. Benito, M. Barriendos \& M. C. Llasat), 269-274. CSIC (Consejo Superior de Investigaciones Científicas), Madrid, Spain.

Llasat, M. C. (1993) Les inondations de 1940 en Catalogne espagnole. Les inondations semblables des cinquante années suivantes, In : L'aiguat del 40. Actes del Congrés de Vernet (1990), Generalitat de Catalunya, Barcelona, 137-146.

Llasat, M. C., Barriendos, M., Barrera, A. \& Rigo, T. (2005) Floods in Catalonia (NE Spain) since the $14^{\text {th }}$ century. Climatological and meteorological aspects from historical documentary sources and old instrumental records. J. Hydrol. 313, 32-47.

Luterbacher, J., Xoplaki, E., Dietrich, D., Jones, P. D., Davies, T. D., Portis, D., Gonzalez-Rouco, J. F., von Storch, H., Gyalistras, D., Casty, C., \& Wanner, H. (2002) Extending North Atlantic Oscillation reconstructions back to 1500. Atmos. Sci. Lett. 2, 114-124.

Mudelsee, M., Börngen, M., Tetzlaff, G. \& Grünewald, U. (2003) No upward trends in the occurrence of extreme floods in central Europe. Nature 425, 166-169.

Naulet, R., Lang, M., Ouarda, T. B. M. J., Coeur, D., Bobée, B., Recking, A. \& Moussay, D. (2005) Flood frequency analysis on the Ardèche River using French documentary sources from the last two centuries. J. Hydrol. 313, 58-78.

Pfister, C., Brázdil, R. \& Glaser, R. (eds) (1999) Climatic Variability in Sixteenth Century Europe and its Social Dimension. Special issue of Climatic Change 43(1), 1-351.

Rico, M. (2004) Las paleocrecidas en la cuenca media del Río Segre durante el Pleistoceno superior-Holoceno: registros morfosedimentarios y análisis hidrológico. PhD Thesis, University of Zaragoza, Spain.

Rodda, J. (2003) The World's maximum observed floods. In: World Catalogue of Maximum Observed Floods (ed. by R. Herschy), xiv-xv. IAHS Publ. 284, IAHS Press, Wallingford, UK.

Sánchez, E., Gallardo, C., Gaertner, M. A., Arribas, A. \& Castro, M. (2004) Future climate extreme events in the Mediterranean simulated by a regional climate model: first approach. Global Planet. Change 44, 163-180.

Sheffer, N. A., Enzel, Y., Benito, G., Grodek, T., Poart, N., Lang, M., Naulet, R. \& Coeur, D. (2003) Paleofloods and historical floods of the Ardeche River, France. Water Resour. Res. 39, 1376.

Thorndycraft, V. R., Benito G., Rico, M., Sánchez-Moya, Y., Sopeña A. \& Casas, A. (2005) A long-term flood discharge record derived from slackwater flood deposits of the Llobregat River, NE Spain. J. Hydrol. 313, 16-31.

van Geel, B., Van der Plicht, J., Kilian, M. R., Klaver, E. R., Kouwenberg, J. H. M. Ressen, H., Reynaud-Farrera, I. \& Waterbolk, H. T. (1998) The sharp rise of $\delta^{14} \mathrm{C}$ at ca. $800 \mathrm{cal}$. BC. Possible causes, related climatic teleconnections and the impact on human environments. Radiocarbon 40,335-350.

Webb, R. H. \& Jarrett, R. D. (2002) One-dimensional estimation techniques for discharges of paleofloods and historical floods. In: Ancient Floods, Modern Hazards: Principles and Applications of Paleoflood Hydrology (ed. by P. K. House, R. H. Webb, V. R. Baker \& D. R. Levish), 111-126. Water Science and Application Series, vol. 5 , American Geophysical Union, Washington DC, USA.

\section{APPENDIX 1}

\section{Dating of the coin found at the Sarría de Ter palaeoflood site}

The coin found underlying the slackwater flood sediments of the Ter River at Sarría de Ter is made of copper and had a value of 8 "maravedies". The coin is a restamping related to a long period of inflation during the reign of Felipe IV (1621-65) and only the restamping in 1651-2 has the coin value written in Arabic numerals (in other re-stampings Roman numerals are used). The first three numbers of the year (1,6 and 5) can also be read on the coin. The coin can be found on p. 308 (type 267) in Calicó et al. (1998). 


\section{APPENDIX 2}

\section{Complete list of documentary and bibliographic sources regarding the 1617 flood in northeast Spain}

\section{Documentary sources}

1) Archive of Aragon Kingdom (ACA), "Dietari de la Deputació", vol. 30, fol. 36, 03/11/1617.

2) Archive of Chapter Cathedral of Barcelona (ACCB), "Exemplaria", vol. 3, fol. 13-15.

3) Archive of Chapter Cathedral of Barcelona (ACCB), "Exemplaria", vol. 4, fol. 6.

4) Archive of Chapter Cathedral of Tortosa (ACCTo), "Actes Capitulars", 1617, s.f., 07/11/1617.

5) Departmental Archive of Eastern Pyrenees (ADPO), "Llibre de Totis", vol. 56, fol. 103, 02/12/1617.

6) Historical Archive of Arenys de Mar, Section II, Ms. 57, Nicolau Morató, "Noticies curioses", fol. 1.

7) Historical Archive of Tarragona (AHT), "Liber consiliorum civitatis Tarracone", vol. 163, fol. 46, 06/11/1617.

8) Historical Country Archive of La Bisbal (AHCLB), "Llibres d'actes", vol. 3, p. 142, 12/11/1617.

9) Historical Country Archive of Manresa (AHCM), "Manuale Consilii", vol. "Fragments", s.f., 09/11/1617, 26/11/1617.

10) Historical Country Archive of Olot (AHCO), "Manual d'Acords", vol. 9, s.f., 10/12/1617.

11) Historical Country Archive of Olot (AHCO), "Manual d'Acords", vol. 9, s.f., 06/01/1618.

12) Historical Country Archive of Reus (AHCR), "Actes municipals", vol. 11, fol. 144, 17/12/1617.

13) Historical Country Archive of Tarrega (AHCT), "Llibres de Consells", vol. 22, fol. 144, 10/11/1617.

14) Historical Country Archive of Terrassa (AHCTas), "Llibre de consells de la Universitat Forana de Terrassa", vol. year 1617, fol. 4, 20/12/1617.

15) Historical Municipal Archive of Barcelona (AHCB), "Dietari del Antic Consell Barceloní", vol. 25, 04/11/1617.

16) Historical Municipal Archive of Gerona (AHCG), "Manual d'Acords", vol. 220, 1617, fol. 133 and following.

17) Historical Municipal Archive of Sabadell (AHMS), "Llibre d'actes del Ple", A.6, 1614-1634, fol. 79, 09/11/1617.

18) Historical Municipal Archive of Sabadell (AHMS), "Llibre d'actes del Ple", A.6, 1614-1634, fol. 80, 12/11/1617.

19) Historical Municipal Archive of Selva del Camp, "Llibre de determinacions del Consell de la vila de la Selva", vol. 1611-1621, s.f., 05/11/1617.

20) Historical Municipal Archive of Tortosa (AHMTo), "Llibres de provisions i acords municipals", vol. 76, s.f., 06/11/1617, 19/11/1617.

21) Library of Catalonia (BC), Manuscripts Section, Ms. 778, "Llibre de les serimonies y coses memorables de la vila de Puigcerdà", fol. 66.

22) Library of University of Barcelona (BUB), Manuscripts Section, Ms. 115, Magí Sevilla, "Historia General del Principado de Cataluña, Condados de Rossellon y Cerdaña. Desde el año 1598 hasta el año 1640", fol. 26.

23) Library of University of Barcelona (BUB), Manuscripts Section, Ms. 1008-1010, Gaspar Vicens, "De cosas varias y notables sucedidas en estos nuestros tiempos", 3 vols. Vol. 1, fols. 251-253.

24) Municipal Archive of Lleida (APL), "Llibres del Consell General", A-437, fol. 111, 05/11/1617.

25) Municipal Archive of Lleida (APL), "Llibres del Consell General", A-437, fol. 114, 12/11/1617.

26) Municipal Archive of Seu d'Urgell (AMSU), "Llibre de Consells", vol. 4, 1617-1657, fol. 4, 03/11/1617.

27) Notarial Archive of Besalu (ANB), Manual 308 (1403), fol. 1. 02/11/1617.

\section{Bibliographical sources}

1) Aguilar, F. A. \& Salarich, J. (1863) Desgracias de Vich, Soler Hnos., Vic, 143 pp.

2) Birba, L. (1962) La Vall de Camprodon, Selecta, Barcelona, 256 pp.

3) Crusellas, F. de P. (1896) Nueva historia del santuario y monasterio de Nuestra Señora de Montserrat, Tipografía Católica, Barcelona, $531 \mathrm{pp}$.

4) Feliu de la Penya, N. (1709) Anales de Cataluña, Josep Llopis (3 vols), vol. 3, 235.

5) Gort, E. (1991) Història de la Cartoixa de Scala Dei, Fundació Roger Belfort, Reus, 465 pp.

6) Junyent, E. (1975) "L'aiguat de 1617 a Vic", Ausa, vol. 8, nr. 149, Vic, 149-155.

7) Porcar, P. J. (1934) Coses evengudes en la ciutat y regne de València. Dietario de Mosén Juan Porcar, capellán de San Martín (1589-1629), Góngora, Madrid, 2 vols.

8) Soler Simón, S. (1994) Memòries d'una família pagesa: els Anglada de Fonteta (ss. XVII-XVIII), Ajuntament de La Bisbal, 113 pp.

9) Valdeosero, M. de (1617) Relación verdadera, que truxo Miguel de Valdeosero Correo de a cavallo de su Magestad, del lastimoso diluvio, que uvo el mes de Noviembre deste año de 1617 en la ciudad de Barcelona, y en otros lugares, y de la perdida de Monasterios, y muertes de muchas gentes, y otros que milagrosamente escaparon, como por la relación se declara, Alonso Rodríguez Garrama, Sevilla, 4pp. 